\title{
Kiina, Kiina, Kiina - ja suomalainen sosiaalipedagogiikka
}

\author{
Juha Hämäläinen
}

М onelle suomalaiselle Kiina näyttäytyy etäisenä ja vieraana. Kouluopetuksessa Kiinaa käsitellään jokseenkin pinnallisesti. Yleissivistykseen kuuluu tietää, että paperi, ruuti, tähtikartat, kompassi, silkki ja posliini ovat kiinalaisia keksintöjä ja että jo ennen ajanlaskun alkua syntynyt kauppareitti, jota kutsutaan silkkitieksi, toimi vuosisatojen ajan Euroopan ja Kiinan välisen kaupankäynnin kanavana.

Kiinalaisen sivilisaation omaperäisyys on vahvistanut vierauden tuntua, vaikka historiassa tunnetaan ajanjaksoja, jolloin Euroopassa on ollut erityistä Kiina-viehtymystä. Kiinnostusta Kiinan kulttuuria ja historiaa kohtaan ovat luoneet muun muassa keskiajalla ilmestynyt Marco Polon matkakertomus, kiinalaisten taide- ja käyttöesineiden yleistyminen lisääntyneen kaupankäynnin myötä sekä kiinalaisten klassikkotekstien erikieliset käännökset.

Maailmansotien välisenä aikana kehkeytyi Kiinan ja Euroopan maiden, myös Kiinan ja Suomen, kesken monenlaista valtiollista ja kulttuurista yhteydenpitoa, joka kuitenkin hiipui toisen maailmansodan jälkeen Kiinan poliittisen ja taloudellisen eristäytymisen vuoksi. Maolainen ideologia ei juuri saanut Suomessa tai laajemmin länsimaissa merkittävää vastakaikua. Kiina pysyi etäisenä ja vieraana Maon kauden loppuun asti.

Nyt on toisin. Maon kauden jälkeen suhteellisen lyhyessä ajassa tapahtunut hätkähdyttävä taloudellinen kasvu on nostanut merkittävästi Kiinan poliittista painoarvoa maailmassa. Globaalissa taloudessa Kiina on tullut lähelle. Se on tehnyt merkittäviä investointeja sekä kehitysmaihin että vauraisiin länsimaihin, ja siitä on tullut huomattava tuotanto- ja markkina-alue monille länsimaisille yrityksille. 
Muutos on lisännyt länsimaissa kiinnostusta kiinalaista sivilisaatiota kohtaan. Suomessakin kansalaisten Kiina-tietoisuutta on pyritty lisäämään ja korkeakoulut ovat alkaneet kouluttaa määrätietoisesti Kiina-asiantuntijoita. Koulutusta korkealle arvostava Kiina näyttäytyy houkuttelevana koulutusvientialueena korkeakouluille ja koulutuspalveluja tarjoaville yrityksille. Kiinalaisen yhteiskunnan ja kulttuurin tuntemus edesauttaa tarkoituksenmukaista kanssakäymistä.

Kiinalaisessa yhteiskunnassa ja kulttuurissa riittää ihmettelemistä. Elämänmuoto perustuu olennaisesti kungfutselaiseen moraalioppiin, joka määrittelee niin perheenjäsenten kuin kansalaisten hyvät tavat ja keskinäiset moraaliset velvollisuudet. Kungfutselainen hyve-eettinen ajattelu tunkee vahvasti läpi yhteiskunnan kaikilla tasoilla. Yhteisöllinen omistautuminen, sitoutuneisuus ja uskollisuus ovat keskeisiä poliittisia arvoja.

Kiinan poliittisen nykyhallinnon autoritaarista toimintaa, joka on vierasta liberaalin demokratian poliittiselle järjestykselle, voi ymmärtää, jos tunnistaa sen yhteydet kungfutselaisen yhteiskunta-ajattelun ihanteisiin. Poliittisessa retoriikassa viljellään toistuvasti ilmaisuja "harmoninen yhteiskunta" ja "sosialismin kiinalainen muoto". Hallinnon keskeiseksi tehtäväksi sen kaikilla tasoilla nähdään kulttuurisen, sosiaalisen ja poliittisen konsonanssin ylläpitäminen.

On hyvä muistaa, että monituhatvuotinen kiinalainen sivilisaatio on rakentunut kulttuurista yhtenäisyyttä luoneelle keisarivallalle. Toisiaan seuranneiden dynastioiden muodostumisiin on liittynyt rajuja valtataisteluja ja erilaisten ideologisten oppisuuntien välisiä konflikteja. Kuitenkin harmonia on kiinalaisen filosofian punainen lanka: niin yksilön harmonia luonnon, itsen ja toisten ihmisten kanssa kuin yhteiskuntaelämän sisäinen harmonia.

Nyky-Kiina on merkillinen yhdistelmä johtajavaltaista hallintoa ja villiä kapitalismia. Sekoitus selittyy - ainakin osin - yhteiskunnallisen ja poliittisen ajattelun kungfutselaisella juuristolla. Kiinalainen yhteiskunta on kyllä keskellä valtaisaa murrosta, jossa perinteiset ja modernit arvot ja pyrkimykset ottavat mittaa toisistaan. Yhteiskunta ei kuitenkaan toimi länsimaisten oikeusvaltioperiaatteiden vaan perinteiselle kiinalaiselle yhteiskunta-ajattelulle tunnusomaisten oikeus- ja moraaliperiaatteiden pohjalta.

Toisin kuin lakiperustaiset länsimaiset yhteiskunnat kiinalainen yhteiskunta on oleellisesti tapaperustainen. Rakenteet eivät perustu montesquieulaiseen vallan kolmijakoon vaan tottumukseen, joka sekoittaa poliittisen ja oikeudellisen vallankäytön. Länsimainen demokratia on lähtökohtaisesti sopimusyhteiskunta, kiinalainen on käskyvaltayhteiskunta, jossa korostuvat sosiaalisiin hierarkioihin perustuva vallankäyttö, tottelevaisuus ja lojaliteetti. 
2000-luvulla Hongkong on muodostunut kiinalaisen ja länsimaisen yhteiskuntajärjestelmän kohtauspaikaksi, suorastaan taistelutantereeksi. Hongkong tuli brittiläisen imperiumin siirtomaaksi 1840-luvulla, ja vuonna 1898 britit laajensivat hallintoaluetta 99-vuotisella vuokrasopimuksella. Kulttuurisesti kiinalainen Hongkong oli poliittisesti brittiläisen hallintokulttuurin vaikutuspiirissä vuoteen 1997, jolloin vuokrasopimus päättyi ja Britannia palautti alueen Kiinalle.

Oikeudellisesti Manner-Kiinaan liitetty Hongkong on erityistalousalue, ja sillä on brittiläisen hallintotavan muovaama laaja itsehallinto, jopa oma oikeuslaitos. Tätä kirjoitettaessa Hongkongin mielenosoitukset ovat jatkuneet puoli vuotta. Ne saivat alkunsa suunnitelmasta säätää laki, joka antaa mahdollisuuden luovuttaa rikoksesta epäiltyjä Manner-Kiinaan. Sittemmin protestoijien listalle on tullut muitakin vaatimuksia, muun muassa vaatimus avoimista demokraattisista vaaleista.

Entä sosiaalipedagogiikka? Tarjoaako sosiaalipedagogiikka näkökykyä terävöittävät silmälasit kiinalaisen yhteiskunnan, kulttuurin ja kasvatuspolitiikan ymmärtämiseksi? Olisiko suomalaisella sosiaalipedagogiikalla jotakin annettavaa kiinalaisille virkamiehille, tutkijoille ja kansalaistoimijoille? Mitä esimerkiksi länsimaisesta sosiaalipedagogiikasta tuttu yhteisöllisyyden korostaminen tarkoittaa vahvasti yhteisökeskeisessä kiinalaisessa elämänmuodossa? Entä sosiaalipedagogisesti tulkittu kansalaiskasvatus? Tai mitä itse voisimme oppia?

Sosiaalipedagoginen katse kohdistuu väistämättä kasvatuskulttuuriin ja yhteiskunnassa vallitseviin kasvatuksen periaatteisiin. Kiinalainen kasvatusajattelu perustuu oleellisesti kungfutselaiseen perintöön, ja vallitseva kasvatuspolitiikka pitää arvossa kungfutselaista tapakulttuuria. Lisäksi kasvatuksen aatepohjassa vaikuttavat buddhalainen ja taolainen kansanuskonto sekä virallisessa kasvatuspolitiikassa marxismin kiinalainen malli. Siinä, missä länsimaisessa kasvatusideologiassa korostuu yksilön vapauden maksimointi, kiinalainen kasvatuspolitiikka suuntautuu kansallisen yhtenäisyyden edistämiseen.

Kiina on vanhastaan koulutuskeskeinen sivilisaatio, jossa koulutuksella saavutettua osaamista on arvostettu korkealle. Tästä yhtenä esimerkkinä on vuosisatainen virkamiestutkintojärjestelmä, jonka tavoitteena on valikoida virkamiesuralle hakeutuvista parhaat: poimia jyvät akanoista ja erottaa eri tasoisiin tehtäviin kykenevät toisistaan. Tähtäimenä on mahdollisimman kyvykäs ja neuvokas, opillisesti sivistynyt virkamieskunta. Voisi kuvitella, että maaperä on otollinen sivistyshenkiselle, kasvatuksen hyvinvointiyhteyttä tutkivalle ja tulkitsevalle sosiaalipedagogiselle ajattelulle. 
Nyky-Kiina on länsimaille houkutteleva koulutusviennin kohde. Suomestakin on hakeuduttu verrattain laajasti Kiinan koulutusmarkkinoille kasvatusjärjestelmän kaikilla tasoilla varhaiskasvatuksesta aina tohtorikoulutukseen. Parhaat ja kestävimmät tulokset mitä ilmeisimmin saavutetaan siellä, missä länsimaisen ja kiinalaisen kasvatusajattelun yhteensovittamisessa onnistutaan ja pedagogiset innovaatiot juurtuvat kiinalaiseen elämänmuotoon.

Mitä annettavaa suomalaisella sosiaalipedagogiikalla - siten kuin alaa tulkitsemme, tutkimme ja opetamme - voisi olla kiinalaisille? Mikä heitä siinä ehkä kiinnostaisi? Arvelen, että kiinnostus koskisi ennen muuta sitä, mitä ratkaisuja sosiaalipedagogiikka tarjoaa kasvatus- ja hyvinvointityön haasteisiin ja erilaisiin yhteiskunnallisiin ongelmiin. Tähän liittyy myös erityinen kysymys itsellemme: miten näemme sosiaalipedagogiikan oppialan suhteessa kiinalaisen yhteiskunnan poliittisiin jännitteisiin, kuten kansalaisten valvontaan, Hongkongin tapahtumiin tai tiedossamme oleviin ihmisoikeusrikkomuksiin?

Tällaiset kysymykset auttavat meitä reflektoimaan ja täsmentämään tulkintaamme sosiaalipedagogiikasta. Miten ymmärrämme alan suhteessa erilaisiin poliittisiin ideologioihin ja järjestelmiin? Pidämmekö sitä esimerkiksi osana länsimaisen liberaalin demokratian agendaa, jota yksilön vapauden ihanne kannattelee, vai katsommeko, että sosiaalipedagogiikka voi asemoitua osaksi sellaisiakin yhteiskunnallisia järjestyksiä, joissa etusijalla ovat muut arvot? Kulttuurisesti ja poliittisesti etäinen Kiina on verraton koetinkivi sosiaalipedagogiikan itseymmärryksellemme.

Kiinalaisen yhteiskunnan sosiaaliset ja ekologiset haasteet ovat mittavat. Perinteisen yhteisöllisen ja modernin yksilöityneen elämäntavan ristiriidat koskevat olennaisesti kasvatuksen periaatteita ja käytäntöjä. Ympäristötietoisuuden ja -vastuullisuuden kysymykset ovat monella tavalla kasvatuskysymyksiä ja jäsentyvät sosiaalipedagogisella ekososiaalisen sivistyksen käsitteellä niin Kiinassa kuin länsimaissa. Sosiaalisten ongelmien luonne, mekanismit ja mittasuhteet ovat Kiinassa kuitenkin monella tavalla erityislaatuisia ja niitä on tarkasteltava niiden omassa sosiaalisessa, kulttuurisessa ja poliittisessa kontekstissa.

Sosiaalipedagogiikan kansainvälisen kehityshistorian kannalta on kiinnostavaa, että yli kaksi tuhatta vuotta kestäneen keisarivallan päättäneen, vuonna 1912 perustetun Kiinan tasavallan opetusministeriössä oli sosiaalipedagogiikan yksikkö. Kasvatuksen sosiaalinen luonne ja merkitys ymmärrettiin. Tämä ymmärrys on tärkeä osa myös nykyistä kiinalaismallisen sosialistisen yhteiskunnan missiota, joskaan sosiaalipedagogiikan käsitteeseen pohjautuvaa hallinnonalaa kommunistisessa Kiinassa ei ole ollut. 
Hongkongin mellakoista olen itsekin saanut osani. Kaksi päivää ennen tämän tekstin kirjoittamista sain tiedon, että kansainväliseen lehteen kirjoittamani artikkeli on läpäissyt vertaisarvioinnin, mutta en voi saada siitä vielä virallista ilmoitusta, koska Hongkongissa sijaitsevassa lehden päätoimittajan yliopistossa on ollut tuhoisa tulipalo ja yliopiston lukukausi on keskeytetty. 
10 - Sosiaalipedagoginen aikakauskirja, vuosikirja 2019, vol. 20 